\title{
THE DEVELOPMENT OF HUMAN RESOURCES IN ISLAMIC FINANCIAL INDUSTRIES FROM ECONOMIC AND ISLAMIC FINANCIAL GRADUATES
}

\author{
Nurul Huda, Nova Rini, Desti Anggraini, Khamim Hudori, Yosi Mardoni
}

\begin{abstract}
The Development Of Human Resources In Islamic Financial Industries From Economic And Islamic Financial Graduates. The purpose of this article is to determine the absorption level of Islamic economics programme graduates into the Islamic financial industry, in Jakarta and West Java. This research used exploratory studies method and Alignment Index (AI). The overall research results, of 2011 until 2014 graduates showed a low level of absorption into Islamic finance industry. Research result showed absorption level in University of Muhammadiyah Prof. HAMKA is by 20\%, Islamic University 45 bekasi absoption level continues to increase from year to year, and Juanda University Bogor absoption level is below 40\%. This occured because the universities curriculum is still dominant in the application instead of the application of soft skills hardskill.
\end{abstract}

Keywords: Exploratory study; Alignment Index; Tracer Study; Islamic economics.

\begin{abstract}
Abstrak. Pengembangan Sumber Daya Manusia Dalam Industri keuangan dan Lulusan keuangan Islam. Tujuan dari artikel ini adalah untuk mengetahui tingkat penyerapan lulusan program ekonomi Islam ke dalam industri keuangan syariah, di Jakarta dan Jawa Barat. Penelitian ini menggunakan metode penelitian eksplorasi dan Keselarasan Index (AI). Hasil penelitian secara keseluruhan, dari 2011-2014 lulusan menunjukkan rendahnya tingkat penyerapan ke dalam industri keuangan Islam. Hasil penelitian menunjukkan tingkat penyerapan di Universitas Muhammadiyah Prof. Hamka adalah sebesar 20\%, Universitas Islam tingkat penyerapan 45 bekasi terus meningkat dari tahun ke tahun, dan tingkat penyerapan Juanda Universitas Bogor di bawah 40\%. Ini terjadi karena kurikulum universitas masih dominan dalam aplikasi bukan aplikasi lembut hardskill keterampilan.
\end{abstract}

Kata kunci: Studi Eksplorasi; Alignment Index (AI); Penelusuran Lulusan; Ekonomi Islam 


\section{Introduction}

The development of the Islamic finance industry in Indonesia began with the emergence of Islamic banking, both the conversion of conventional banks and non convertible. The development of Islamic banks give effect to the development of non-bank financial institutions that operate based on Islamic economic system. The development of the Islamic finance industry is characterized by ratings received from appraisal Indonesia Global Islamic Finance Report (GIFR) in 2013, GIFR in 2013 ranked Indonesia as fifth in the world, as countries with promising potential development of the Islamic finance industry after Iran, Malaysia, Saudi Arabia, and United Arab Emirates. The development of Islamic banks is quite impressive, with an average asset growth, more than $65 \%$ in the last five years. It is to be expected that the Islamic banking industry's role in supporting the national economy will increasingly significant in years to come.

The development of the Islamic finance industry have encourage the development of Islamic economics studies programme, such as Islamic economics programme and Islamic banking programme, as well as another course based on sharia. Islamic economic studies programme graduates are expected to be the work force of Islamic financial industry in Indonesia, but the expectations of the founders of Islamic economics courses are not in accordance with reality.

The research results of University of Indonesia in 2003 showed that more than 90\% of Islamic Bank employees does not have of Islamic economics educational background. That indicated there was a gap between Islamic economics programme graduates with the absorption of Islamic economics programme graduates into the Islamic finance industry.

The gap between Islamic economic programme graduates with Islamic economic graduates absorption level occurs in all financial industry in Indonesia, including in Jakarta and West Java. Jakarta and West Java had been an area of interest, because to be seen as the the center of the Islamic finance industry development, to be analyzed regarding the absorption of Islamic economics programme graduates in Islamic Finance Industry.

There are several university in West Jawa area that have Islamic economic programme study, and in Jakarta only one university that has Islamic economic programme study. This study will analyze the absorption of Islamic economic programee graduates into Islamic finance industry in Jakarta and West Java. Islamic Economics curriculum development is actually based on five grounds, namely normative treatises, the empirical socio-economic conditions, market demand, comparative advantages and demands of the times as well as the global trend.The religious values in this case Islam must be internalized (learned, studied, 
understood, conceived, believed) then externalized (practiced) by economic actors in all economic activity without exception whatsoever and under any circumstances, in order to achieve falah (welfare afterlife). The consequence is that all economic activity must be intentional as worship because the purpose of human life is none other than just to worship God. In fact, right now also has developed teaching and education of Islamic economics started secondary level to universities both within and outside the country. This reality is an opportunity for state and private universities to develop its economy, especially faculty teaching Islamic economics.

Robst define aligned (match) as the suitability of education or field of study that is held by workers with work undertaken now. College graduates can work in conditions that suit their competence or not with the field work. Conditions under which work somewhat related to the field of competence of the workers may be called by partially mismatched and conditions under which work is completely unrelated to the fields referred to completely mismatched. While Sloane in Robst (2007) states that workers who fall into this category are those that are mismatched appropriate education level but the type of education is not in accordance with his work. If the jobs that are not held in accordance with the competence fields of education studies it can be said there is no alignment between jobs with workers' competence.

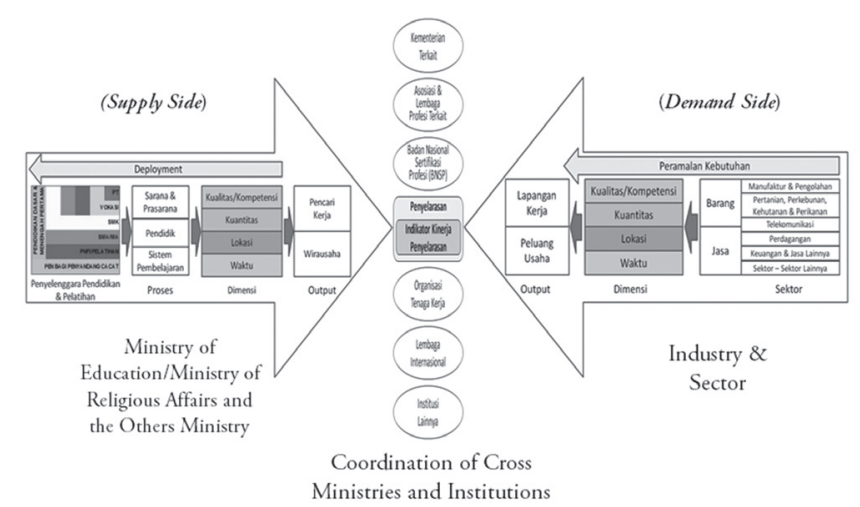

Source: Ministry of Education, synchronizers team, modified

Figure 1. Alignment Framework

Demand model designed in the model concept of alignment must be able to produce the information needs of the workforce and business opportunities in the labor market and also to provide an overview of functions and roles should be given by the Ministry of Manpower and all the ministries that promote various sectors 
of economic activity include manufacturing and processing, the agricultural sector (agriculture, plantation, fisheries and forestry), the telecommunications sector, the trade sector, transport sector, public works/construction and financial sectors and other services (Tim aligning Ministry of Education). Alignment Framework for Education with the workplace mentions that the market-driven approach in an effort alignment of education with the world of work, giving the consequence that the supply side or education should strive to respond to the dynamic needs of the workplace.

Quality of work refers to the quality of human resources, quality of human resources refer to: First, Knowledge namely the ability of the employees who are more oriented towards intelligence and think power and mastery of broad employee owned; Second, Skill, ability and technical mastery of a specific field operations owned by employees; Third, Abilities, which is ability formed from a number of competency of an employee that includes loyalty, discipline, teamwork and responsibility. While Flippo argued about the quality of work as follows: "Although every organization is different views on the standard of work quality of employees, but in essence the effectiveness and efficiency become common measure." Based on the definition given by Flippo, it can be said that the core of quality work is an outcome that can be measured by the effectiveness and efficiency of the work carried out by human resources or other resources in achieving the goals or targets companies with good and efficient.

Yorke and Knight in Agustin introduce the concept of employability or ability to work that is defined as a set of achievement includes the skills, understanding, and personal attributes more enables graduates to gain employment and be successful in the choice of works and provide benefits for themselves, the workforce, society, and economy as a whole. Work environmental proved hard skills can be defined as the technical procedures or tasks that can be observed and measured. While soft skills, which is usually interpreted to mean "human skills" are not easily seen, although very needed in working life. These skills can be categorized into three main categories, which is the properties of personal, interpersonal skills, and the skills to overcome problems and make decisions. Previous literature by Kemper and McMurchie, said that hardskills and soft skills complement each other. The same thing, the research by Spencer and Spencer, indicating that workers are workers who have superior technical skills and good manners.

In the study of Islamic human resources, human as driving a production process, must have the characteristics or traits that inspired shifatul Anbiya or the prophets personalities. These personalities include: Siddiq (right). Itqan (professional), fathanah (smart), amanah (Honest / can be trusted), and tabgligh (invite to the 
truth). According Agustianto (2011) in Sari, qualifications and standards of Islamic human resource are: first, Understanding the moral values in the application of jurisprudence muamalah/Islamic economics. Second, comprehending on Islamic economic concept and purpose. Third, understand the concept and application transactions (contract) in muamalah Islamic economics. Fourth, knowing and understanding the working mechanism of economic institutions/financial/banking/ Islamic business. Fifth, knowing and understanding the mechanism of action and interaction of relevant institutions; regulators, supervisors, legal institutions, consultants in economics industrial /finance/banking/Islamic business.

Muhammad (2003) said there are several types of human resource qualifications required in Islamic financial institutions: First, specialist on Islamic who understand economics (category type A). Second, specialist on Economics who recognize Islamic (category type B). Third, the human resources that have expertise in Islamic and economics (category type $\mathrm{C}$ ). Type $\mathrm{A}$ is expected to contribute to normative aspects in the area of Islamic economic system (Islamic financial institutions). While type B is expected to perform the positive economic analysis on operational of Islamic economic system. Type $\mathrm{C}$ is the one that is most expected in the Islamic financial institutions.

Alignment Index Model (AI) is an alignment of performance measurement model that uses the approach of the supply side. Alignment Index (AI) is an index that measures how much alignment has been reached between the world of education with the workplace. AI is calculated from how much education graduates produced is absorbed in the the workplace with conditions aligned according to the fourdimensional alignment of the dimensions of quantity, quality/competence, location, and time. Alignment program is a program that is comprehensive from the supply side to the demand side. In this study, the model of performance measurement alignment will be directed to better accommodate conditions as the supply side of labor supply.

Demand side would vary in all sectors of the field of business (industrial goods and services). Therefore, in formulating the program alignment between supply side and demand side is needed is comprehensive representation of the future of some relevant dimensions. Based on the framework of the alignment and definition of alignment has been built upon, then there are four dimensions required in the alignment are: first, dimensions of quantity; Second, dimensions of Quality; Third, dimensions of location; and Fourth, dimension of time.

Exploratory research is research that aims to explore/search for variables or factors contained in a phenomenon/conditions/particular social setting and exploration of the unknown or not much information available about it or a place 
or a particular situation. Exploratory research methods will involve three main components, which is qualitative techniques, secondary data analysis, and field research.

\section{Literature Review}

Research/graduate literature review on the gap between Islamic financial programme graduates and labor requirements in the Islamic finance industry until now there has been a lot done by researchers. Amalia doing research on now Condition Survey and Analysis of Teaching Economics and Islamic Finance In PTAI And PTU. Amalia mentions that the research results in terms of quality of Human Resources, Sharia Financial Institutions is still limited, and has not met the required competence and qualifications. Alumni are not ready for more than a theory or concept operational techniques learned during their education in universities, therefore the Islamic financial industry is more likely to adopt a conventional employee is then given a short training on the concept of sharia.

Hasan's research was entitled Analysis of Islamic Banking Industry in Indonesia, produce that university graduates are not in accordance with the needs of communities and businesses that exist. High unemployment among scholars of this is due to lack of skills outside the core competency as an undergraduate. This certainly proves that as a bachelor's degree does not guarantee employment. Not surprisingly, the graduates still have difficulty obtaining a job that suits her abilities at this time.

Kartikasari's research focused to analyze how large the gap between higher education input accounting, which is prospective students, with the output, which is with the industry, in terms of number and of the level. In addition, it also seeks to describe the interest of the input and output requirements for consideration for higher education providers of accounting in preparing the curriculum and networking strategy input.

By using descriptive statistical methods to the results of a survey of 1970 students of high school, 40 companies, and the study documents the newspaper clippings for one year in the year to September 2013, this study indicates that the quantity of output produced by the organizers of accounting education in Batam is still in the range of incoming mind the needs of the industry. However, a gap large enough to interest the input and output needs of higher education accounting views of his education. Therefore, higher education providers in Batam need to socialize this gap to avoid oversupplied in Undergraduate level and undersupplied at Diploma level. 
Ayu and Hastuti (2010) wrote research analysis on the concord of graduates competence with requirements of taxation's competency at the corporate, found a significant difference between the expected competencies with the provided competencies for the external tax payers and internal tax payers, then there was a significant difference between the expected competencies in external tax payers and the internal tax payers. The method of data analysis was descriptive statistics.

\section{Methods}

This research used quantitative and qualitative approach. Quantitative method was done to get output, namely demand, supply and gap of human resources in Islamic Economy and finance. Whereas qualitative approach was conducted to find out the problems, solutions and strategies of human resources in Islamic Economy and finance practitioner that related to the supply gap in market of human resource in Islamic Economy and finance. Then, in this research would be designed Alignment Index (AI) model. AI was calculated from how much graduates that was produced in education world absorbed in the work world with aligned conditions according to four harmonization dimension that was quantity dimension, quality/competence, location and time. AI cannot calculate demand or labor requirement which was demanded by the industry. Because the calculation base of AI was amount of graduate who absorbed in the work world compared with the amount of graduates. To find out the problems, solutions, and strategy, in this research used exploratory research method.

The data which collected was primary data and secondary data that obtained through surveys and interviews. The data was collected by interviewing that assisted by questionnaire, voice recorder and video recorder/ handy cam. The survey was conducted to determine supply Islamic finance Human Resources, which was based on the capacity of the Public University (PTU) and Islamic University (PTAI) which organized program of study that was Islamic Economics and Finance for Bachelor's Degree. Survey was done at the Directorate-General of Higher Education Ministry had Research Technology and Higher Education as an institution that gives permission and accreditation for public colleges, and Higher Education Directorate of the Ministry of Religion as an institution that gave permission and accreditation of Islamic University (PTAI).

Individual depth interview and focus group discussions were implemented to get more information on the problems, solutions and strategies of human resources in Islamic economy and finance practitioner that concerned gap at market of human resources in Islamic and financee. The purpose was to find information that will assist researchers in formulating the problems, solutions and strategies more 
Al-Iqtishad: Jurnal Ilmu Ekonomi Syariah (Journal of Islamic Economics) Vol. 8 (1), January 2016

precisely. Supporting information was done by finding the data from the literature, reports, mass media such as news / opinion / statements to officers and observers of the Islamic financial Industry that was published in print / on-line, and previous studies that had been published.
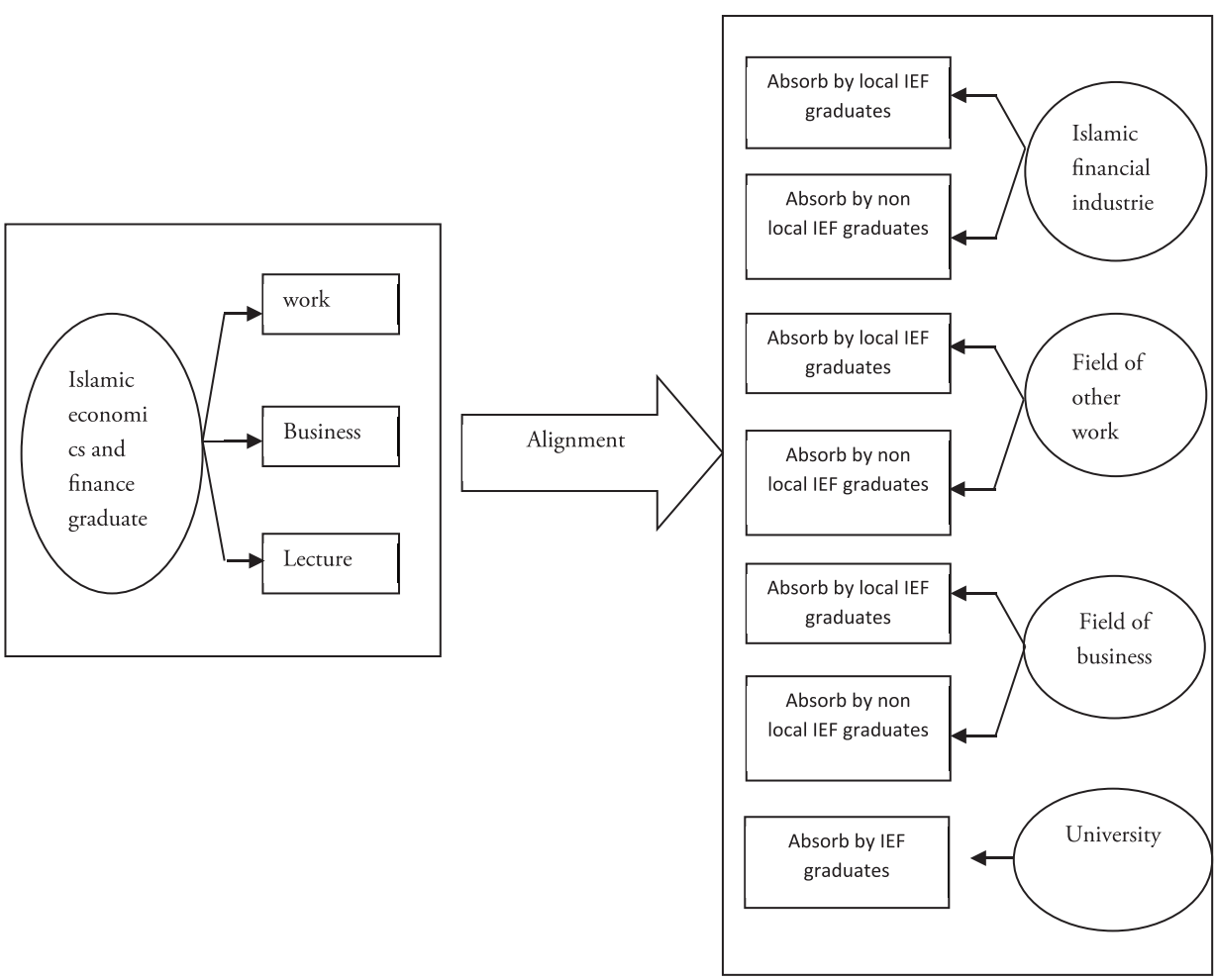

Figure 2. Conceptual Model Alignment Index for Graduate of Islamic economics and finance

Technique of data analysis in this research was quantitative and qualitative analysis: First, quantitative analysis. Quantitative analysis used statistical technique to calculate the demand, supply and gap of economy human resources and Islamic financial. To determine the ideal conditions of human resources in Islamic economics financee, that was compatibility between demand and supply with the perception, expectations, plans and policies of the Islamic financial industry players, both in terms of quantity and quality. Second, qualitative analysis. In this research, qualitative analysis was conducted to analyze the data obtained through the Individual depth interviews and focus group discussions. The steps of data 
analysis were started from data reduction, data display and then make a conclusion and verification. Data reduction at this stage was conducted to select the data that relevant with the purpose of research, information from the field as a raw material that will be summarized, compiled more systematically, and highlighted the important data so that it was easier to control. Display the data was used to see the whole picture or certain parts of the overall picture. The draw of concussion was done to compare suitability between statement of subject of research and the meaning that was contained in the research. Verification intended for assessment of compatibility with the intent of the data contained in the basic concepts in research precisely and objectiveely.

The conceptual model of the Islamic economics and financee was built on the pattern of Islamic economics and financee graduates which was obtained from tracer study. The pattern was simplified into a conceptual model on the supply side. While the demand side adjusts of absorptive of Islamic economics and financee graduates that refers to the results of tracer study. The pattern of Islamic economics and financee graduates was shown in Figure 2.

The mathematical model was based on a conceptual model that had been created. The following was Alignment Index's Properties which includes the definition, purpose, calculation methods, formulas, interpretations, and other properties. First, definition. An index that measured how much absorption had been achieved between education world (college) and absorption of college graduate in employment, business field, and University. In employment will divided graduate that was absorbed in Islamic Financial Industry and Non Islamic Financial Industry. Second, purpose. To find out how much alignment that was achieved as measured by how much graduates produced by universities absorbed in the world of work as an employee, in the business world as an entrepreneur and college as a student. Third, method of calculation. Divide between the number of graduates who are absorbed in jobs, the field of business and universities, and the number of graduates of the number of college graduates. Fourth, the formula this was the basic construction formula Index of Economy Alignment and Islamic financial:

AI Total $=$ AI WIFI + AI Businessman +AI Works NIKS + AI Lecture (1)

Where is :

$$
\begin{aligned}
& \text { AI work IFI }=\frac{W I F I}{T G} \\
& \text { AI work NIFI }=\frac{W N I F I}{T G}
\end{aligned}
$$


$\begin{aligned} \text { AI Businessmen } & =\frac{B}{T G} \\ \text { AI Lecture } & =\frac{L}{T G}\end{aligned}$

Annotation :

$\mathrm{AI}=$ Alignment Index

IFI = Islamic financial industry

NIFI = Non Islamic Financial Industry

WIFI = Wor at Islamic financial industry

WNIFI = Wworking at non Islamic financial industry

$\mathrm{B}=$ Businessman

$\mathrm{L}=$ Lecture (postgraduate level)

TG = Toctal graduate

AI value for the graduate of Islamic economics and financee (IEF) will combine two elements, namely AI Total and AI IEF. AI IEF had parameters, $(\mathrm{t})=$ graduate of economy and Islamic financial in the year $(t)$. With the variable $(t)$ of AI IEF, then can be formulated into a new equation, namely:

$\mathrm{AI}$ if $=$ total $\mathrm{AI}_{\text {wifi }}^{\mathrm{t}}$

$\mathrm{AI}$ value range is $0 \leq \mathrm{AI} \mathrm{IEF} \leq 1$. Getting closer to one (1) indicates the level of alignment the better. Conversely the near zero (0) indicates the level of alignment that is less good or bad. IEF AI is said to be good when the AI work in the Islamic finance industry is higher than the AI work in except Islamic financeial industry, entrepreneurial AI and AI Lecture.

\section{Results and Discussion}

Exploratory study on this research was done at universities which have graduate in 2011 to 2014, in public and private universities that have graduate in Islamic economy and financial programme. For Jakarta region, after conducting a survey toward universities that have graduate of economy and Islamic financial, the result showed only one university that have graduate of economy and Islamic financial, namely Muhammadiyah Prof. Dr. Hamka University. In West Java region was found two university that become object of the research, that was Djuanda Bogor University and UNISMA Bekasi. Actually, there were several Universities in West Java that had been implemented program of study economy and Islamic 
financial and also have graduate from that program. However, there was obstacle in collecting the data that was caused by less of tracer study conducted by the universities, made it difficult to track the absorption of graduate in industries.

\section{Special Capital Region of Jakarta}

For Jakarta area there was only one university conducting a program of study economy and Islamic financial. The University was Muhammadiyah Prof. Dr. Hamka University. In that university, there was program of study Islamic Banking under the Islamic religion faculty. Based on secondary data that was obtained from the Muhammadiyah Prof. Dr Hamka University, it was known that in the program of economy and Islamic financial continued experiencing an increase every year. In 2011 there were as many as 28 people graduate of Islamic Economics and finance program at Muhammadiyah Prof. Dr Hamka University. The number of graduates increased close to 100 percent in 2012, which were 54 people. In 2013 and 2014 the number of graduate continued to increase, to 88 people and 98 people. Based on the results of tracer study was done by Muhammadiyah Prof. Dr Hamka University known that are two patterns of graduate as in Figure 3 above, that was working in the Islamic financial industry and continued studying in Magister degree. Graduate who work in the Islamic financial Industry in 2011 was the most widely compared with the following year. In 2011, there were 5 people was known graduate who work in the Islamic financial industry. The number of graduate who work in the Islamic financial industry was experiencing a decline in 2012, where in 2012 there were only 4 of alumnus who work in the Islamic financeial industry, with details of 2 graduates was work in Islamic bank, one person at a Islamic Rural Bank and 1 person in BMT. In 2013 only one person graduate of economy and Islamic financial that worked in the Islamic financial industry. In 2014, there were not graduate of Islamic economics and financee which worked in the Islamic financial industry.

The data of graduate that continued study to Magister Degree in Muhammadiyah Prof. Dr. Hamka University also not much. In 2011 and 2013, there was only one graduated of Islamic economics and Finance who continued study in magister degree. Whereas in 2012 only one graduate. However, there were 3 graduates of Islamic economics and financee program that continued study to magister degree.

\section{West Java}

In the region of West Java there were two universities that were the object of the research, namely the University of Juanda and Unisma Bekasi. Islamic banking was one of programs under the Faculty of Islamic Studies (FAI) in 
Unisma Bekasi. Islamic Banking in Unisma had been accredited by BAN PT with grade B. Learning curriculum was designed to mastery of concepts and practices of Islamic Banking operations so that graduate will get bachelor's degree of Islamic economics (S.E.Sy) who have expertise in managing Islamic bank and Islamic financial institutions non-bank. In 2010 there were 13 people graduate of Islamic banking program in Unisma. In 2011 none graduate of Islamic banking Program study. In 2012 there were only 3 people in the program of study of Islamic banking. In 2013 and 2014 the number of graduate of program study Islamic banking was 8 people. Based on tracer study that was done by Unisma, graduate of program study of Islamic banking in 2010, five of them worked in the Islamic financial industry, then one of graduate continued study to magister degree and 4 people worked Non Islamic Financial Industry. Then, in 2012 only one people worked in Islamic Financial Industry, then 2 people worked in Non Islamic Financial Industry, specifically in the conventional financial institutions. In 2013, graduate of Islamic banking that worked in Islamic financial industry quite a lot, as many as 4 people, where 2 people work on Public Islamic bank and 2 people work in Islamic financial bank. In 2013 there was also one graduate of Islamic banking that worked as a teacher.

In Djuanda Bogor University, there was also a program of study economic and Islamic financial. Based on the results of tracer study that was done Djuanda Bogor University. Based on the data of tracer study that was done by Djuanda Bogor University, from 9 graduate of program of study in Islamic economics and financee in 2011, 3 people worked in Islamic financial industry. From 3 people who worked in Islamic Financial Industry, 2 people worked in Islamic Bank, and 1 worked in institution of Zakat. Based on the data was known 1 people work as businessman and 1 worked in Non Islamic Financial Industry. Graduate of Islamic economics Finance at Unida in 2011 only 2 people worked in Islamic Financial Industry. In 2013 was 16 people, 3 of them worked in Islamic Financial Industry, 3 people as businessman and 5 people worked in Non Islamic Financial Industry, and 5 people continued study to magister degree. Graduate in 2014 was same with previous year was 16 people. From 16 people who graduate in 2014, 4 people worked in Islamic Financial Industry, where 3 people worked in public Islamic bank and 1 people worked in Islamic financial bank. Then, in 2014 there were 3 people worked as businessman, and 4 people worked in Non Islamic Financial Industry, and 1 people continued study to magister degree.

In 2012 there are only 3 graduated student of Islamic banking programme, the number is increasing in 2013 and 2014, there are 8 graduated student of Islamic banking programme. Based on tracer study conducted by UNISMA, in 
2010, student who have graduated from Islamic banking programme, 5 of whom worked in Islamic finace industry. One person continued his/her studies taking post graduated programme and 4 person worked in non related Islamic finance industry. In 2012, only one graduated student worked in Islamic finance industry, two graduated student worked outside Islamic finance industry, they worked in conventional finance institution. In 2013 graduated, the number of graduated student whom worked in Islamic finance industry have increased, there are 4 graduated student, 2 of them work in Islamic bank, two person worked in Islamic financing bank. One graduated worked as a teacher. In 2014, the number of student graduated from Islamic banking programme have increased, there are 5 graduated student who worked in Islamic finance industry, one person as a entreupeneur, and one person worked as a teacher.

Based on tracer study conducted by Universitas Juanda Bogor, on their graduated student of Islamic economic and finance programme. Based on tracer study conducted by Universitas Djuanda Bogor, from all 9 graduated student of Islamic economic and finance programme in 2011, 3 person worked in Islamic finance industry, from those 3 graduated student, two person worked in Islamic bank and one person worked in a Badan Amil Zakat one of Islamic finance institution. One graduated student worked as an euntrepeneur and one person worked outside Islamic finance industry.

In Unida Bogor, Islamic economic and finance programme in 2011, had two graduated student, both of them worked in Islamic finace industry. In 2013, there were 16 graduated student, three person worked in Islamic finance industry, three person work as an entreuperneur, five person worked outside Islamic finance industry, also 5 person whose continued their study to post graduated programme. In 2014, the number of graduated student remain the same, 14 person, four person worked in Islamic finance industry, of those 4 person, 3 person worked in Islamic bank and one person worked in Islamic finance institution. There are 3 person of the 2014 graduated worked as an euntreupeneur, 4 person worked outside Islamic finance industry and one person continued to post graduated programme.

\section{Implementation of AI Model}

AI EKS model which being implemented in Universitas Muhammadiyah Prof. Dr Hamka DKI Jakarta, Unisma Bekasi dan Universitas Djuanda Bogor can be discribe below. Alignment index (AI) Universitas Muhammadiyah Prof. Dr. Hamka DKI Jakarta in year 2011-2014 can be calculated in formula described below, 


$$
\begin{aligned}
\text { AI total } & =\frac{W I F I}{T G}+\frac{W N I F I}{T G}+\frac{B}{T G}+\frac{L}{T G} \\
& =\frac{5}{28}+\frac{0}{28}+\frac{0}{28}+\frac{2}{28} \\
& =0,178+0+0+0,018 \\
& =0,25
\end{aligned}
$$

AI total $=\frac{W I F I}{T G}+\frac{W N I F I}{T G}+\frac{B}{T G}+\frac{L}{T G}$

$$
=\frac{4}{54}+\frac{0}{54}+\frac{0}{54}+\frac{1}{54}
$$$$
=0,074+0+0+0,018
$$$$
=0,09
$$

AI total $=\frac{W I F I}{T G}+\frac{W N I F I}{T G}+\frac{B}{T G}+\frac{L}{T G}$

$$
=\frac{1}{88}+\frac{0}{88}+\frac{0}{88}+\frac{2}{88}
$$$$
=0,011+0+0+0,022
$$$$
=0,03
$$

$$
\begin{aligned}
\text { AI total } & =\frac{W I F I}{T G}+\frac{W N I F I}{T G}+\frac{B}{T G}+\frac{L}{T G} & \\
& =\frac{0}{98}+\frac{0}{98}+\frac{0}{98}+\frac{3}{98} & \\
& =0+0+0+0,03 & \text { AI ief }=0,03 \mathrm{AI}_{0}^{2014} \\
& =0,03 & \text { r }
\end{aligned}
$$

Alignment index (AI) Universitas Islam 45 Bekasi based on the result of the tracer study in 2011-2014 can be calculated as below:

$$
\begin{aligned}
\text { AI total } & =\frac{W I F I}{T G}+\frac{W N I F I}{T G}+\frac{B}{T G}+\frac{L}{T G} & \\
& =\frac{1}{3}+\frac{2}{3}+\frac{0}{3}+\frac{0}{3} & \\
& =0,33+0.67+0+0 & \text { AI ief }=1 \mathrm{AI}_{0,33}^{2012}
\end{aligned}
$$




$$
\begin{aligned}
\text { AI total } & =\frac{W I F I}{T G}+\frac{W N I F I}{T G}+\frac{B}{T G}+\frac{L}{T G} \\
& =\frac{4}{8}+\frac{1}{8}+\frac{0}{8}+\frac{0}{8} \\
& =0,5+0,125+0+0 \\
& =0,625 \\
\text { AI total } & =\frac{W I F I}{T G}+\frac{W N I F I}{T G}+\frac{B}{T G}+\frac{L}{T G} \quad \text { AI ief }=0,63 \mathrm{AI}_{0,5}^{2013} \\
& =\frac{5}{8}+\frac{1}{8}+\frac{1}{8}+\frac{0}{8} \\
& =0,625+0,125+0.125+0 \quad \text { AI ief }=0,875 \mathrm{~A}_{0,625}^{2014} \\
& =0,875 \quad
\end{aligned}
$$

Alignment index (AI) Universitas Djuanda Bogor based on the result of the tracer study in 2011-2014 can be calculated as below :

$$
\begin{aligned}
\text { AI total } & =\frac{W I F I}{T G}+\frac{W N I F I}{T G}+\frac{B}{T G}+\frac{L}{T G} \\
& =\frac{3}{9}+\frac{1}{9}+\frac{1}{9}+\frac{0}{9} \\
& =0,33+0,11+0,11+0 \\
& =0,56 \\
\text { AI total } & =\frac{W I F I}{T G}+\frac{W N I F I}{T G}+\frac{B}{T G}+\frac{L}{T G} \\
& =\frac{2}{3}+\frac{0}{3}+\frac{0}{3}+\frac{0}{3} \\
& =0,67+0+0+0 \\
& =0,67 \\
\text { AI total } & =\frac{W I F I}{T G}+\frac{W N I F I}{T G}+\frac{B}{T G}+\frac{L}{T G} \\
& =\frac{3}{16}+\frac{5}{16}+\frac{3}{16}+\frac{5}{16} \\
& =0,19+0.31+0,19+0,3 \mathrm{AI}_{0,33}^{2011} \\
& =1 \\
\text { AI total } & =\frac{W I F I}{T G}+\frac{W N I F I}{T G}+\frac{B}{T G}+\frac{L}{T G} \\
& =\frac{4}{16}+\frac{4}{16}+\frac{3}{16}+\frac{1}{16} \\
& =0,25+0.25+0,19+0,06 \\
& =1
\end{aligned}
$$


AI model which had been implemented in all three universities have showed different results. The result is being influenced by the data collected in the tracer study. In addition, the different result in each universities can also be explained, because all three universities, each had different character of graduates. AI total calculation from three universities, Unisma in 2012 and Universitas Juanda Bogor in 2013 and 2014 resulted in the highest total AI, perfect AI value. This condition shows the absorption of graduates in economics and Islamic finance programee at Unisma in 2012 and Universitas Juanda Bogor in 2013 and 2014 are very good.

AI model which calculated 2011 graduates, showed that AI value for Universitas Juanda Bogor based from AI from graduates whom work in Islamic economic and finance industry (0.33) is greater than AI value for Universitas Muhammadiyah Prof. Dr. Hamka (0.178). Meanwhile Unisma Bekasi AI value can not be calculated, because they don't have any graduate from Islamic economic and finance programme in 2011. Based on AI value above can be concluded that Universitas Juanda Bogor is able to produce more graduates from Islamic economic and finance programme who work related in Islamic and finance industry, compare to Unisma Bekasi and Universitas Muhammadiyah Prof. Dr. Hamka

The result of AI value based on graduates whom work in Islamic economic and finance industry in 2014, Unisma Bekasi AI value show that they relatively had better graduates absorption compare to Universitas Juanda Bogor and Universitas Muhammadiyah Prof. Dr. Hamka. Unisma Bekasi AI value score highest value of AI value graduates whom work in Islamic economic and finance industry. In 2014, Universitas Muhammadiyah Prof. Dr. Hamka AI value show that they in that year did not produce any graduates in Islamic economic and finace programme which can be absord into the industry.

AI value Universitas Juanda Bogor, in 2011, showed same result for AI based on graduates who work outside Islamic economic and finance industry and for AI based on graduates who became entrepreneur, which is 0.11. Meanwhile in 2011, both Universitas Muhammadiyah Prof. Dr. Hamka and Unisma Bekasi had zero score, for AI value based on graduates who work outside Islamic economic and finance industry and for AI based on graduates who became entrepreneur. However Unisma Bekasi showed higher AI value based on graduates who continued persue to take post graduated programme (0.018) compare to Universitas Juanda and Universitas Muhammadiyah Prof. Dr. Hamka, which mean that Unisma Bekasi is more able to produce graduates who continued persue to take post graduated programme.

In Universitas Muhammadiyah Prof. Dr. Hamka, AI value based on graduates who continued persue to take post graduated programme, based on 2011 to 2014 
data, show an increace value year by year, which means that the number of graduates from Islamic economic and finance programme who continued to persue post graduated programme keep increasing every year.

According to AI Value based on graduades who became an entrepeneur in three universities, Universitas Djuanda Bogor had higher AI value compare to Unisma Bekasi, Universitas Muhammadiyah Prof. Dr. Hamka had zero value, based on tracer study known previously, which mean graduates absorption to entrepeneurship is low.

In general based on 2011-2014 data, result showing low level of graduates absorption into Islamic economic and finace industry. Universitas Muhammadiyah Prof. Dr. Hamka showed level of absorption not even at $20 \%$, which can be viewed by AI Value score of 0.2 . This AI value indicated that only small percentace of Islamic economic and finance graduates who work at the Islamic economic and finance industry it self.

Because of tracer study is not well being conducted by many university, we can not fully describe the absorption level of Islamic economic and finance graduates into the industry it self. Unisma Bekasi showed an increasing level of absorption of graduates from year 2011-2014. This relates to the programs carried by Islamic Banking Programme UNISMA in the form of cooperation with Islamic financial institutions for programs miniature bank laboratory practice.

Universitas Djuanda Bogor showed level of absorption their Islamic Economic and Finance Programme not even at 40\%. The low absorption of economics and Islamic finance graduated to the Islamic finance industry can be seen from several perspectives. The study exploratory performed on the academia in this case the study program of economics and Islamic finance from the college that became the object of research suggests that the universities in this case study program economics and Islamic finance is still not accommodate the needs of the Islamic finance industry in terms of providing economics and Islamic finance human resource.

Informants statement showed that Islamic Banking programme curriculum still not related to user or Islamic finance industry needed. They need curriculum based on practice. It cause the number of Islamic economic and finance graduate and Islamic banking programme graduate is less absorbed in Islamic Finance Industry.

In Alignment Framework between Education and working world (Alignment team, 2010) stated that market-driven approach to align education and working world give consequences that education as an input have to response the working world need. 
Efforts to harmonize the needs of the Islamic financial industry by providing human resources of Islamic economic and finance have been done but still constrained. The Role of human resource in an organization or company is very important, even as important as the work itself. Therefore, the competence of human resources is also a very important thing. Soft skill competency more needed than hardskill competency in Islamic Finance Industry in Indonesia. Result of explanatory study showed soft skill of human resource of Islamic economic and finance are less than other human resource.

According to Antonio in Sari (2014), professionals are needed in the Islamic finance industry is unique if compared to conventional industry. The professional on Islamic finance industry are required to have scientific competence and skill that combining Islamic science and finance. Islamic principles should be "dissolved" in the operational aspects of Islamic finance institution, including in designing banking products and Islamic financial structures, financial and contract execution, liquidity and balance sheet management, and risk management.

Character of Islamic economics graduated that exists today is far from ideal character of Islamic human resource. The ideal character of human resource according Suma is Zikr, PIKIR and MIKR. Where the concept of ZIKR include: first, Zero Base, the concept of individuals who view everything with a pure. Second, Faith, Human Resources believers will give an indication that whatever is done will always be seen by God so that it will always avoid fraud and ethics violations. Third, Consistent, isalmic human resource is consistent in every movement, attitude, and his word will be able to produce a good productivity. Fourth, Result oriented, human resources capable of combining the concept of a zero base, faith and consistent will produce optimum result for common progress (result oriented).

Educational imbalance in the lecture hall are more reliant on hard skills, need to be addressed, such as by giving more weight to the development of soft skills. Implementation of these soft skills can be done through the curriculum. Curriculum developed to meet the needs and demands of society profession (professional needs), industrial society (industrial needs) and society at large (societal needs). Society asks and require graduates who have personal competence (soft skills) and competencies of professions (hard skills). Personal competence contains more elements of attitude, whereas the competence of professionalism more emphasis on the ability to use knowledge and skills with the wisdom in the field. 


\section{Conclusion}

Based on research, there are the conclusion: Overall of graduates in 2011 till of 2014 showed a low level absorption at the Islamic finance industry. At Muhammadiyah University Prof.Dr. Hamka not even reach 20\%, it is seen from the AI works on the Islamic finance industry which is still below 0.2. At Islamic university 45 bekasi shows the level of absorption continues to increase from year to year. While at the Universitas Djuanda Bogor as a whole showed absorption rate of the Islamic Economic and Finance graduates are still below 40\%. Academician in this case study program of Islamic Economics and Finance, still not accommodate the needs of the Islamic finance industry in providing human resource of Islamic Economic and Finance thus necessary to develop competency-based curriculum that meets the needs and demands of society profession (professional needs), industrial society (industrial needs ) and society at large (societal needs).

\section{References}

Agustin, V. (2012). Kompetensi Lulusan Sarjana Strata 1 (S1) Psikologi dalam Menghadapi Dunia Kerja Pada mahasiswa Perguruan Tinggi " $X$ ”. Calyptra: jurnal Ilmiah Mahasiswa Universitas Surabaya Vol.1 No.1.

Amalia, E. \& Al Arif, M.N.R. (2013). Kesesuaian Pembelajaran Ekonomi Islam di Perguruan Tinggi dengan Kebutuhan SDM Pada Industri Keuangan Syariah di Indonesia, Jurnal Inferensi STAIN Salatiga, Vol 7, No. 1.

Amalia, E. (2014). Survey dan Analisis Kondisi Kini Pengajaran Ekonomi dan Keuangan Syariah Di PTAI dan PTU. Disampaikan Pada Forum Riset Keuangan Syariah 2014, Bogor, 14 Oktober 2014

Ayu, D \& Hastuti, R. (2010). Analisis Kesesuaian Kompetensi Lulusan Dengan Kebutuhan Kompetensi Perpajakan Pada Dunia Usaha (Survey Perusahaan Berskala Sedang dan Besar Di Semarang). (Research Report). Universitas Katolik Soegijapranata Semarang.

Azis, I.J. (2003). Analytic Network Process with Feedback Influence, A New Approach to Impact Study. Journal, University of lullinois, Urbana-Campaign.

Flippo, E.B. (2002). Personel Management. International Edition. New York: McGraw Hill Book Company

Ginting, J.M. (2012). Proyeksi Kebutuhan Sumber Daya Manusia (SDM) Perbankan Syariah dan Skenario Pemenuhannya. (Unpublished Thesis). Depok: University of Indonesia.

Hasan. (2011). Analisis Industri Perbankan Syariah di Indonesia. Jurnal Dinamika Ekonomi Pembangunan, Juli 2011, Volume 1 Nomor 1. 
Kartikasari, D. (2013). Analisis Kesenjangan Antara Input Dengan Output Pada Pendidikan Tinggi Akuntansi Di Batam. Artikel Manajemen Bisnis dan Politeknik Negeri Medan.

Kumar, R. (2005). Research Methodology: A Step-by-step Guide for Beginners. Ohio : Pearson Prentice Hall.

Matutina. (2001). Manajemen Sumber Daya manusia Perusahaan. Bandung: PT. Remaja Rosdakarya

Mintaroem, H.K. (2009). Kurikulum Ekonomi Syariah di Fakultas Ekonomi Universitas Airlangga dan Perannya dalam Perekonomian Indonesia. Materi disampaikan pada Forum Dekanat PTN se-Indonesia, tanggal 22-24 Oktober 2009 di Fakultas Ekonomi Universitas Padjajaran

Muhammad. (2003). Kualifikasi Sumber dayaManusia di Lembaga Keuangan Syariah. Al-Mawarid, Edisi X tahun 2003.

Robst, J. (2007). Education and Job Match: The Relatedness of College Major and Work. Economics of Education Review.

Sari, Nilam. (2014). Re-Design Kurikulum Ekonomi Syariah Perguruan Tinggi Agama Islam:(Sebuah Upaya Melahirkan Sumber Daya Manusia Profesional. JIP-International Multidisciplinary Journal. Vol 2 Nomor 3, September 2014, pp. 135-154.

Shakir, R. (2009). Soft Skills at the Malaysian Institutes of Higher Learning. Asia Pacific Educ. Rev., 10, pp. 309-315. 